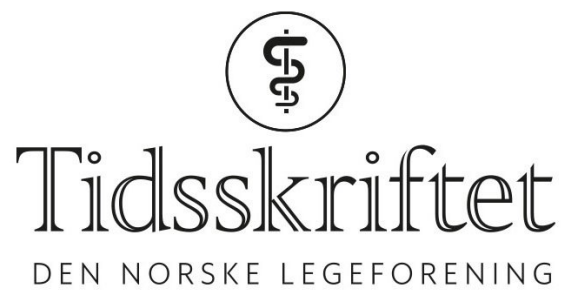

\title{
Å mobilisere, lete og finne - anomi ved afasi
}

KOMMENTAR

\section{LINE HAALAND-JOHANSEN}

E-post: line.haaland-johansen@nord.no

Line Haaland-Johansen er logoped MNLL. Tilsatt som stipendiat (logopedi, profesjonspraksis) ved Nord universitet.

Forfatteren har ikke oppgitt noen interessekonflikter.

Tell utfordrer begrepet ordletingsvansker (1). Som alternativ nevner han ordfinningsvansker, noe språkforskerne Landmark og Hansen gir sin tilslutning til (2). Tell finner ordfinningsvansker litt tungt. Han ser ordmobiliseringsvansker som mulig alternativ, men mener det kan virke konstruert. Han foreslår beskrivelser: "pasienten har ordleting», «har problemer med å finne enkelte ord».

La meg tilstå med det samme. Som logoped har jeg mange ganger både sagt og skrevet «ordletingsvansker». Tell kommenterer at det jo ikke er slik at pasienten sliter med å lete etter ord, men med å finne ord. Skulle jeg våge meg på å være litt uærbødig, kunne jeg skrevet at, vel, det er vel ikke komplett feil å si at disse personene strever med letingen. Ikke sjelden kan letingen være både krevende, ineffektiv og resultatløs. Men naturligvis har Tell helt rett. Jeg er enig. Det er da også svært mange år siden jeg lot meg overbevise av en klok kollega. Hun sa vi burde bruke ordfinningsvansker eller ordleting. Begge deler fungerer godt. Selv bruker jeg nok ordleting oftere enn ordfinningsvansker. Tenker vi afasivennlighet og klarspråk, er ordleting et godt alternativ.

Som fagterm vil jeg allikevel også slå et slag for ordmobiliseringsvansker. Ordmobilisering (word retrieval) og ordfinning (word finding) vil av noen brukes synonymt.

Ordmobilisering som fagterm impliserer imidlertid at det å «lete og finne» ikke er hele historien når vi skal få frem ord. Å mobilisere ord er en lang, komplisert, gjentakende og ikke strengt lineær prosess, fra et begreps- eller budskapsnivå frem mot en muntlig eller skriftlig språklig ytring. Ordmobiliseringsvansker er slik et godt begrep. Det brukes da også per i dag i utstrakt grad av logopeder, for eksempel i relasjon til arbeid med personer med afasi.

Det er interessant at Tell ikke nevner anomi, til tross for at han bruker begreper som parafasi og perseverasjon. Anomi er nettopp ordleting eller ordmobiliseringsvansker. Begrepet brukes mye i logopedi (også utover anomisk afasi). Anomi er kun brukt tre ganger i tidsskriftets nettutgave; alle ganger i betydningen «sosial anomi», to ganger med eksplisitt referanse til sosiologen Durkheim.

En generell oppfordring til slutt: La oss si afasi! Tell sier innledningsvis at "[p]roblemer med å finne ord kan være uttrykk for en lett dysfasi (...)». Et søk viser at man i legetidsskriftets 
nettutgave oftere bruker afasi (107 treff) enn dysfasi (14 treff). En bra trend. En fagartikkel (3) oppfordrer: Let's call it aphasia! De påpeker at når to begreper brukes om hverandre om det samme, vil det gi gevinst å endre til enhetlig terminologi. Dysfasi (språkvansker) og dysfagi (svelgevansker) lyder dessuten for likt til at man kan forsvare at begrepet dysfasi brukes, når det gode alternativet afasi finnes (3).

\section{LITTERATUR:}

1. Tell N. Ordletingsvansker? Tidsskr Nor Legeforen 2019; 139. doi: 10.4045/tidsskr.19.0o6o. [CrossRef]

2. Landmark AMD, Hansen P. Bruk ordfinningsvansker! Tidsskr Nor Legeforen 2019; 139. doi: 10.4045/tidsskr.19.059o. [PubMed][CrossRef]

3. Worrall L, Simmons-Mackie N, Wallace SJ et al. Let's call it “aphasia”: Rationales for eliminating the term “dysphasia”. Int J Stroke 2016; 11: 848-51. [PubMed][CrossRef]

Publisert: 18. november 2019. Tidsskr Nor Legeforen. DOI: 10.4045/tidsskr.19.069o

(C) Tidsskrift for Den norske legeforening 2020. Lastet ned fra tidsskriftet.no 